\title{
Does Infrastructure Matter In Tourism Development?
}

Seetanah B*

Faculty of Law \& Management, University of Mauritius

Reduit

Email: $\underline{\text { b.seetanah@uom.ac.mu }}$

\section{Juwaheer T D}

Faculty of Law \& Management, University of Mauritius

Reduit

Email: roubina@uom.ac.mu

\section{Lamport M J}

Faculty of Law \& Management, University of Mauritius

Reduit

Email:m.lamport@uom.ac.mu

\section{Rojid S}

Email: srojid@worldbank.org

\section{Sannassee R V}

Faculty of Law \& Management, University of Mauritius

Reduit

Email: rvsan@uom.ac.mu

\section{Subadar Agathee U}

Faculty of Law \& Management, University of Mauritius

Reduit

Email: usubadur@uom.ac.mu

Paper Accepted on 07 January 2011

\begin{abstract}
This paper investigates the significance of infrastructure as a factor in destination development. The classical demand for international tourism function is extended to include a proxy for infrastructure. An application involving the island of Mauritius is presented whereby total tourist arrivals as well as arrivals from
\end{abstract}


Europe/America, Asia and Africa are modelled. The findings show that tourists are sensitive to the infrastructure of the island, particularly those from Europe/America and Asia. Tourism infrastructure, income of tourists, distance, and relative prices are important ingredients in their own respect in the tourism demand equation.

Keywords: Infrastructure, Tourism, Dynamic Panel data

*For correspondences and reprints

\section{INTRODUCTION}

There exists a significant literature investigating the determinants of tourism flows (see Lim, 1997). Income in country of origin, the cost of travel, relative prices, exchange rates and tourism infrastructure are among the most prominent determinants of tourism flows in the existing empirical literature. A number of authors, including Gunn (1988) and Inskeep (1991), have cited the infrastructure base of a country as a potential determinant of the attractiveness of a tourism destination. Infrastructure forms an integral part of the tourism package. For instance, road infrastructure enhances accessibility of tourists to different parts of the destination country while sound airport infrastructure ensures that tourists experience a comfortable transition from the plane into the borders of the destination country and vice versa. As such communication infrastructure allows quick and cheap communication between the origin and destination country as well as provides maximum information about the destination thereby reducing uncertainty, fear and asymmetric information. Other infrastructure such as waste water and energy among others are also believed to result in more reliable services and thus enhance the attractiveness of the destination.

The cultural diversity, racial harmony and political stability of Mauritius makes the island an attractive tourist destination. Tourist arrivals have increased at an annual average growth rate of about 7\% over the last three decades, up from 103,000 in 1977 to 761,000 in 2005 and to around 800000 in 2007. The tourists in 2007 were mainly from Europe (65\%) and Africa (25\%), followed by Asia (6.5\%), Australia 
(1.7\%) and America (1.2\%). Tourism receipts amounted to about 16\% of GDP in 2007, confirming the fact that the tourism industry is indeed a pillar of the Mauritian economy. Mauritius has to date been essentially a beach resort par excellence, but the authorities have recently started diversifying the product base using the concept of eco-tourism.

This paper models tourist arrivals into Mauritius over the period 1985 - 2006 from various parts of the world, namely Europe and the United States, Asia, and Africa, with a view to understand the contribution of different determinants in explaining the success of the island as an international tourism destination. Indeed it is noteworthy that the authorities in Mauritius have long recognised the importance of sound infrastructure in promoting tourism development in the island. The networks of roads and communication together with the waste water and energy infrastructure have been subject to massive investment and expansion since the mid 1980s. In the light of these developments, we believe that Mauritius presents itself as an interesting case whereby the effect of infrastructure on tourist arrivals into the island can be usefully studied. This paper does so by extending a classical demand for international tourism function to include an infrastructure proxy. Panel data equations of tourist arrivals from various parts of the world into the island over the period 1985 - 2006 are estimated. The data is further segregated into three continental panel sets (Europe/America, Asia and Africa) to enable a comparison of the determinants of tourist arrivals from different continents in the promotion of the Mauritian destination.

The rest of the paper is organised as follows: section 2 discuses briefly the theoretical underpinnings and empirical works related to the infrastructure-tourist nexus, section 3 provides an overview of the tourism sector in Mauritius, section 4 presents the econometric framework and discussion of the results and section 5 concludes. 


\section{INFRASTRUCTURE AND TOURISM DEVELOPMENT}

\subsection{Theoretical Underpinnings}

Gunn (1988) denotes the tourism product as a complex consumptive experience that results from a process where tourists use multiple of services (information, relative prices, transportation, accommodation, and attraction services) during the course of their visit. Other economic and political conditions and structural features are also important factor shaping many tourist experiences and contribute to the nature of the destination product. Murphy et al (2000) related this type of product to a supply and demand analysis and described how various components of the destination interact with travelers during their trip.

Smith (1994) was among the first to acknowledge the role of service infrastructure in creating a product experience. He argued that "service infrastructure is housed within the larger macro-environment or physical plant of the destination" (Smith, 1994:pp 54). He stressed the fact that the level, use, or lack of infrastructure and technology in a destination (for example transportation, water and power supply, use of computer technology and communications among others) are also visible and determining features that can enhanced the visitors' trip experience. Other authors subsequently supported his views (Choy 1992; Buharis 2000; Crouch and Ritchie 2000). They posited that tourists' overall impression develops their image of a destination after their visitation and that infrastructure may play an important role in that respect.

Crouch and Ritchie (2000) interestingly summarised (Figure 1) the various factors that together make a tourist destination experience attractive. They highlighted the importance the service infrastructure layer, which includes transport services, in the tourist destination experience. 
Figure 1: The tourist destination experience

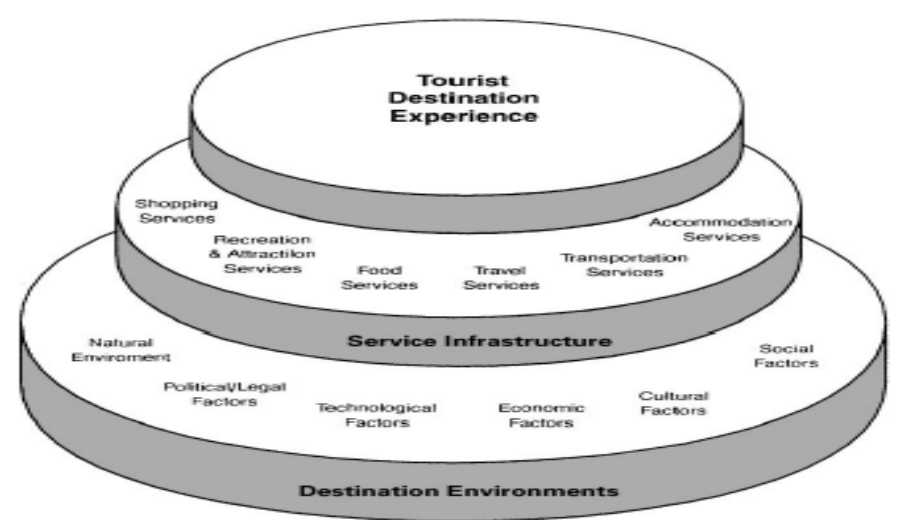

Source: Crouch and Ritchie (2000)

The tourist destination product is also better understood in the context of comparative and competitive advantage. Figure 2, which is adapted from earlier work of Crouch and Ritchie (1999), depicts a global picture of the determinants of a destination's competitiveness. The authors argued that factor conditions are important determinants of attractiveness as tourists travel to a destination to receive the destination experience. Every element has been categorised under core attraction and supporting elements. We focus on the supporting factors and resources component. The destination's general infrastructure services in this category in fact represent one of the most important factors. The tourism phenomenon relies heavily on public utilities and infrastructural support. Tourism planning and development would not be possible without roads, airports, harbors, electricity, sewage, and potable water. The infrastructural dimension is thus a necessary element for tourism development and the above factors are all basic elements for attracting visitors to a destination. Generally, infrastructure has not been included in empirical works because it is expected to be available at a destination and has not been promoted as an attraction factor. Smith (1994), and Crouch and Ritchie (1999) provide a good theoretical treatment of the role of service infrastructure in creating a tourism product experience 
Figure 2: Destination competitiveness and sustainability

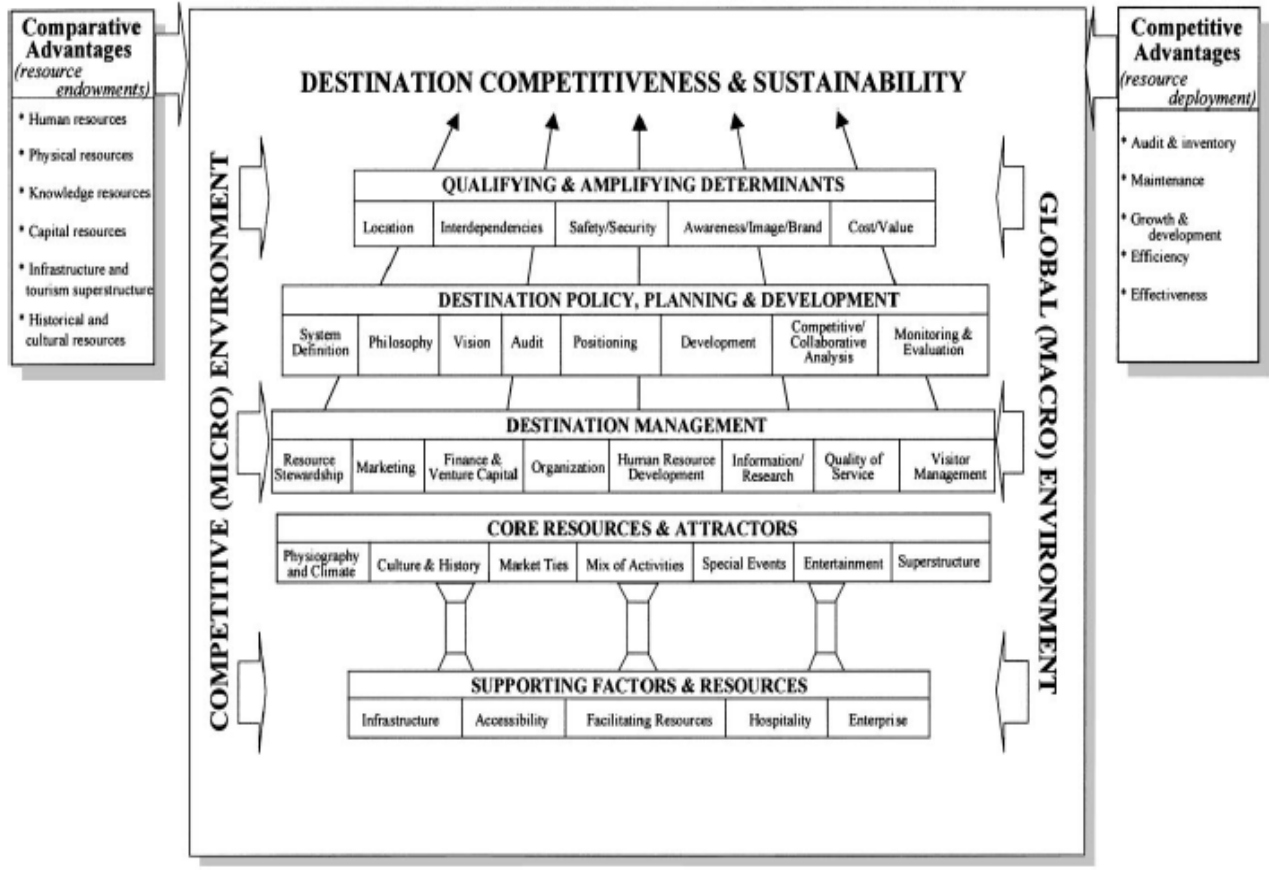

Source: Adapted from Crouch \& Ritchie (1999)

Kaul (1985) also recognizes the importance of infrastructure, more specifically transport as an essential component of successful tourism development in that it induces the creation of new attractions and the growth of existing ones. The Tourism Task Force (2003) of Australia asserts that infrastructure is a big part of the tourist equation. For instance it is posited that the transport system is responsible for connecting tourism-generating regions to tourism-destination regions as well as providing transport within the tourism destination. It should be easy to get to and around in tourism destinations. (Prideaux 2000).

Inhabitants of developed countries, from where the majority of tourists originate, are used to modern transport infrastructure that enables high quality service. These tourists prefer to maintain essentially the same comforts as at home while traveling (Cohen, 1979; Mo, Howard and Havitz, 1993). In fact, Mo, Howard and Havitz (1993), using survey methodology, find that tourists prefer to travel to countries that have the same infrastructures as in their home country. Prideaux (2000) 
argued that if the ability of tourists to travel to preferred destinations is inhibited by inefficiencies in the transport system such as uncompetitive prices or lengthy and uncomfortable journey, the likelihood that they will seek alternative destinations may increase.

Tourism resorts have also often been cited as an important attractor of tourism, especially for the high-class segment. Prideaux (2000) posited that a critical mass of public infrastructure (including transport) is essential for enabling the establishment of high-quality resorts in a country. If this critical mass is not available, the operators would have to incur these infrastructure costs, thereby adding to the capital and operating costs of tourism development and thus reducing competitiveness.

\subsection{Empirical Evidence}

Gearing et al (1974) study the case of Turkey as a tourist destination and find that infrastructure (comprising roads, water, electricity, safety services, health services, communications and public transportation) is a key determinant explaining tourist arrivals. Tang and Rochananond (1990) conclude that infrastructure is an important element in promoting Thailand as a tourist destination country. More recently, Kim et al (2000) in discussing the case of Sun Lost City, South Africa, and McElroy (2003) in discussing small islands highlight the importance of infrastructure, particularly government financed infrastructure, in the success of a destination.

The second type of studies is based on the estimation of an international tourism demand equation. Witt and Witt (1995) and Lim (1997) provide a comprehensive overview of the regression analysis, model specification, attributes and proxies. Income in country of origin, the cost of travel, relative prices, exchange rate, tourism infrastructure and the level of development in the destination country are among the most common determinants of tourist arrivals in the literature. The majority of studies models aggregate tourist arrivals thereby disregarding the effect of the country of origin. The role of transport infrastructure in destination 
development has typically not been considered in the models. To date, regression analysis has overwhelmingly concentrated on developed country destinations.

A recent exception is Naude and Saayman (2004) who study the determinants of tourism flows in the case of African countries using panel data regression approach. Applying cross section Ordinary Least Squares (OLS) as well as static and dynamic panel data estimation, these authors identify political stability, personal safety, tourism marketing efforts and available infrastructure as important factors in addition to the classical usual factors in nearly all panel sets analysed, namely aggregate tourist arrivals, arrivals from America, Europe and Africa respectively. However the measure of infrastructure used relates to tourism infrastructure exclusively.

An investigation of the role of infrastructure exclusively, making use of panel regression analysis to explain tourist arrivals from different origin countries into small island economies is, to our knowledge, nonexistent. It is believed that the findings of our work constitute a useful supplement to the existing literature and to be of significant relevance to island economies, most of which are tourism-based.

\section{TOURISM IN MAURITIUS}

Mauritius is well known by holiday-makers from around the world as an up-market travel destination. Domestically, tourism has been a key engine of economic growth and development since the early 1980s. It is today among the most important pillar of the Mauritian economy. The tourism sector in Mauritius has consistently recorded robust performances over the past five years. The number of tourists coming to the island in 1975 was 74,597 and has steadily increased to 150,000 in 1985 and further to 291,550 in 1991. The rising trend further continued in 1998 with 570,000 tourists. The number of tourists visiting Mauritius in 2005 has gone up to 761,063 (representing a ten-fold increase between 1975 and 2002). Tourist arrivals rose from 681,648 to 761,063 between 2002 and 2005, representing an increase of more than 11\%. The 2004-2005 growth rate was of the 
order of 5.9\% and 825,000 tourists have been visiting the island in 2006, a rise of 8.4\% over 2005. Figures below present the rising trend in total tourist arrivals, tourism earnings and the distribution of tourist arrivals in Mauritius. Some key figures about the Mauritian Tourism Sector are shown in figures 3, 4, 5 and table 1 below.

Figure 3: Tourist Arrivals in Mauritius, 1972-2006*

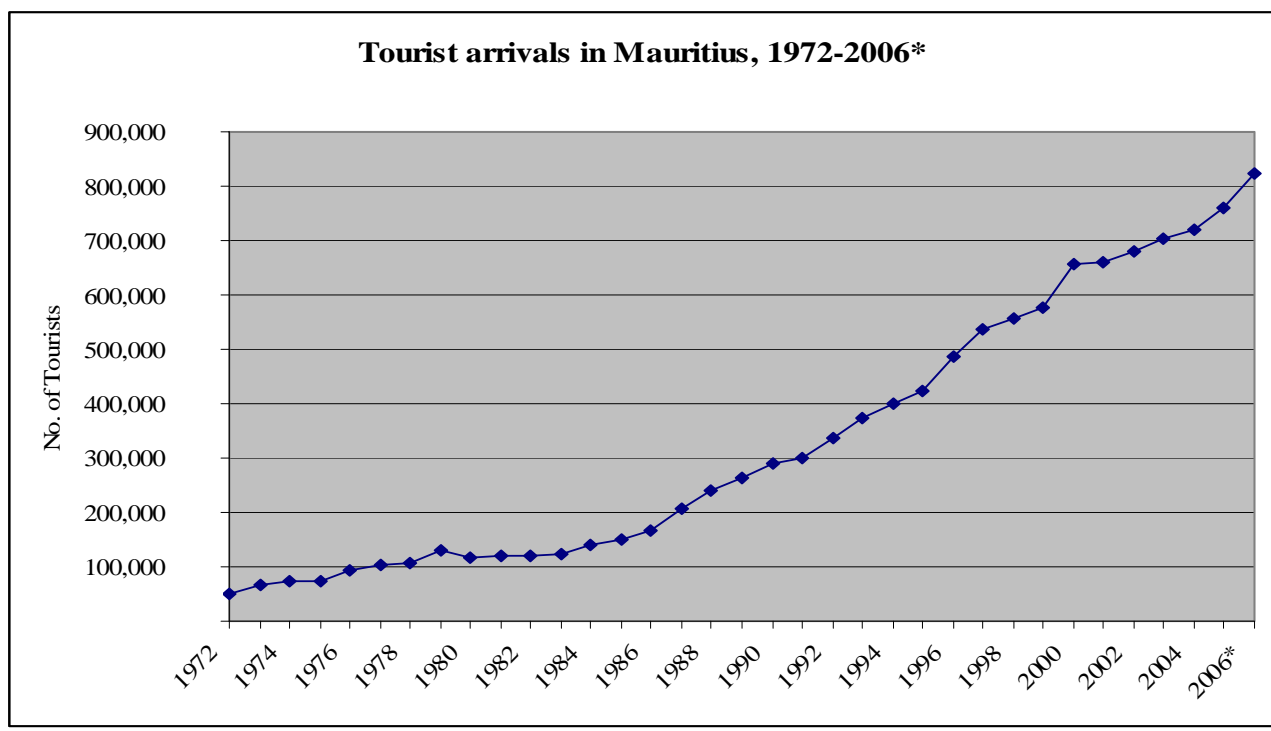

Source: Central Statistical Office Note: The figure for 2006 is a forecast.

Figure 4: Percentage Distribution of Tourist Arrivals by Country of Residence, 2005

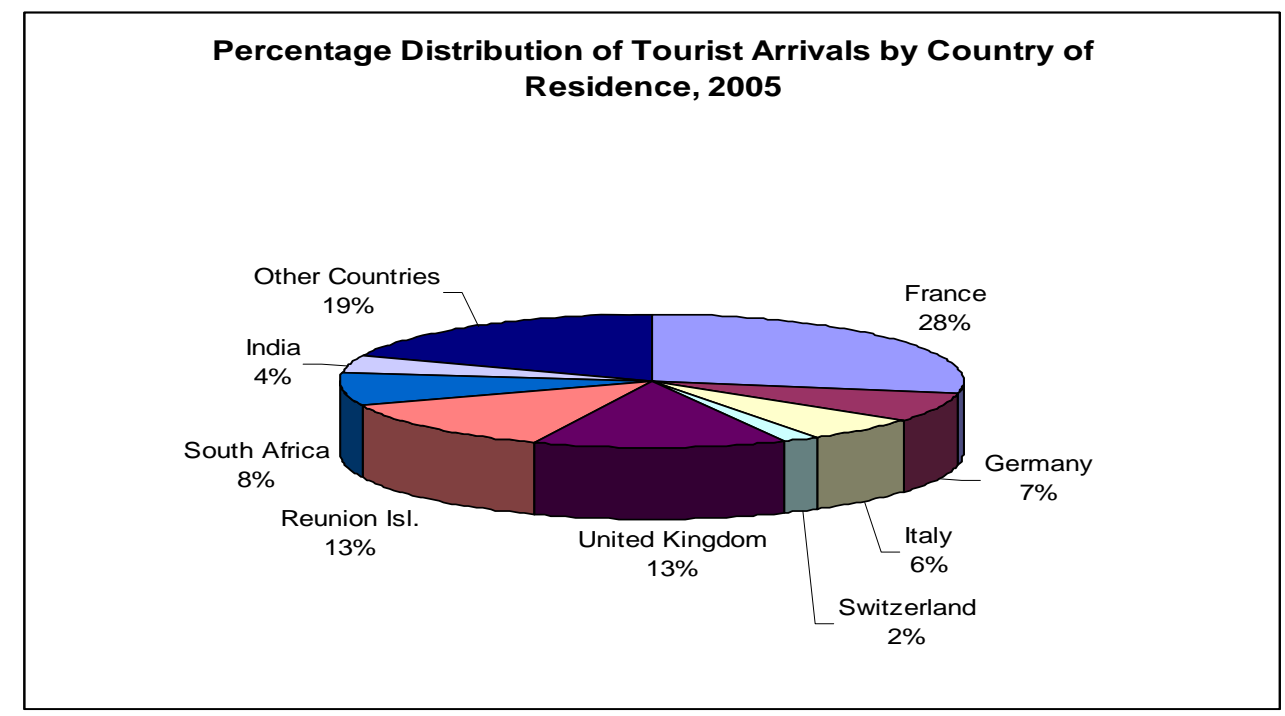


Source: Central Statistical Office

Figure 5: Tourism Receipts, Rs million, 1972-2005.

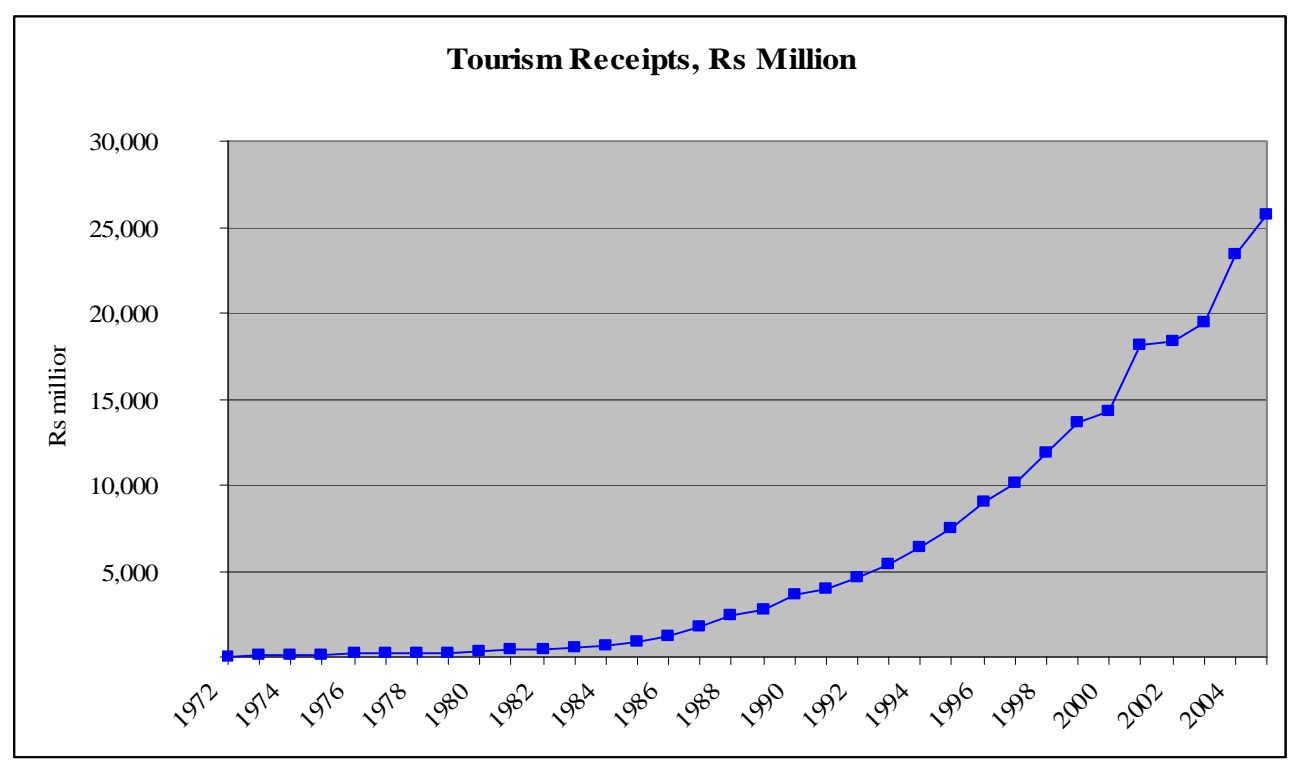

Source: Central Statistical Office

In the early 1970s, earnings from the tourism sector were very low amounting to only Rs 52 million in 1972. By 1987 gross tourist receipts had grown thirty-fold to Rs 1,786 million. This phenomenal increase in receipt increased to Rs 3,940 million in 1991 and to date earnings from the tourist industry stands at around Rs 26,000 million.

The good performance in tourist arrivals can partly be attributed to the perception that Mauritius is a secure destination and to the promotional efforts made by the Mauritius Tourism Promotion Authority (MTPA) in Europe and India. Moreover, emerging markets such as Austria, Spain and Australia are rapidly growing. One should also acknowledge the different strategies that have been implemented by the Mauritian government to attract tourists. Mauritius offers a number of attractions to tourists in terms of a wide range of hotels, accessibility, beautiful beaches and richness in 
culture. Of interest to us, it should be noted that government also invested heavily in public infrastructure, including transportation, which has provided the necessary support infrastructure for tourism in Mauritius. Accumulation of transport infrastructure, particularly air and land transport, is believed to have been an important element in the tourism equation of Mauritius. This is because the island is only accessible by air transport from the major tourist generating countries and such mode of transport is thus crucial. Moreover, Mauritius can boast about having one of the best inland transportation systems and other infrastructure of the continent which have made traveling within the tourism destination (to attraction, hotels shopping) easier, more comfortable and reliable.

Table 1: Some key figures about the Mauritian Tourism Sector

\begin{tabular}{|l|c|c|c|c|c|c|c|c|c|}
\hline & 1980 & 1990 & 1998 & 1999 & 2000 & 2001 & 2002 & 2003 & 2006 \\
\hline $\begin{array}{l}\text { Population } \\
\text { ('000) }\end{array}$ & 1060 & 1080 & 1159.7 & 1174.4 & 1186.1 & 1189 & 1190.3 & 1195.4 & 1197.5 \\
\hline No. Hotels & 43 & 75 & 90 & 92 & 95 & 95 & 95 & 97 & 110 \\
\hline $\begin{array}{l}\text { Hotel } \\
\text { Rooms }\end{array}$ & 2101 & 4603 & 6809 & 7267 & 8255 & 8657 & 9024 & 9647 & 10233 \\
\hline $\begin{array}{l}\text { Tourist } \\
\text { arrival } \\
\text { ('000) }\end{array}$ & 115 & 291.5 & 558.1 & 578 & 656.5 & 660.3 & 681.6 & 702 & 810 \\
\hline $\begin{array}{l}\text { Tourism } \\
\text { Receipt } \\
\text { (million) }\end{array}$ & 7500 & 9207 & 11890 & 14668 & 14234 & 18166 & 18238 & 19397 & 21865 \\
\hline $\begin{array}{l}\text { Tourism } \\
\text { Receipts } \\
\text { (\% of } \\
\text { GDP) }\end{array}$ & $6 \%$ & $10 \%$ & $13 \%$ & $13 \%$ & $14 \%$ & $15 \%$ & $16 \%$ & $17 \%$ & $20 \%$ \\
\hline
\end{tabular}

Source: CSO (2007)

\section{MODEL SPECIFICATION AND DATA SOURCE}

The study uses panel data to investigate the importance of transport capital in the overall tourist attractiveness of Mauritius. We specify a classical demand function for international tourism along the lines of Witt and Witt (1995) and Naudee and Saayman (2004), Seetanah and Khadaroo (2007), and augment it with the public infrastructure. The resulting function is: 


$$
T R_{i t}=f\left(R_{E L A T I V E}, G_{i t} D P F_{i t}, \text { ROOM }_{i t}, \text { DISTANCE }_{i t}, \text { INFRAS }\right)
$$

We use i to index country of origin and t to index year of arrival. The dependent variable TR, the total number of tourist arrivals per annum, is a measure of the demand for tourism to Mauritius. The data are available from the Central Statistical Office (Tourism section) of the island. We draw from the existing literature to identify the independent variables. Real Gross Domestic Product per capita in country of origin (GDPF) is used as a proxy for the spending capacity of tourists. A positive coefficient for variable GDPF in equation (1) would imply that the Mauritian tourism product is a normal good while a negative coefficient would imply an inferior good.

The CPI of the destination country (here Mauritius) adjusted by the US\$ exchange rate is used as a proxy for relative tourism prices (RELATIVE). Naudee and Saayman (2004) argue that the inverse of this variable shows the many baskets of goods a tourist has to give up in his home country in order to buy a basket of goods in the destination country. This measure of relative prices captures changes in the real exchange rate over time as well as cross sectional variation in the cost of travel. Demand for the tourism product in a particular destination is likely to be negatively related to relative tourism prices, as higher cost of living within the destination would make tourists less enthusiastic about that destination.

To capture tourism infrastructure, we follow the standard literature and use rooms available (ROOM) in the destination country. The more rooms there are the higher the capacity and the more competitive is the tourism sector (cheaper price as a result of competition). In any case a minimum number of rooms must be available for a destination to reach its critical mass and also to convince airlines to establish routes. Data on the number of rooms were obtained from the Central Statistical Office of Mauritius. 
Distance between the origin and destination countries has also been widely included when modeling tourist arrival (see Witt and Witt 1995). The longer the distance, the higher the airfare and the higher the level of discomfort and opportunity cost. Distance is likely to have a negative effect on tourist arrivals. Distance (DISTANCE) is measured by the air distance in kilometers between the origin and destination countries and is obtained from Gallup, Sachs and Mellinger (1997).

For the purpose of our analysis we have augmented the classical tourism demand function with public capital stocks (INFRAS) of Mauritius. This stock has been constructed using the Perpetual Inventory Methodology (PIM), which has been widely used in the literature (see Lighthart 2000; Kamps 2003 among others). The PIM computes the value of the capital stock by accumulating past purchases of assets over their estimated service lives appropriately adjusted for the rate of depreciation. The implementation of the PIM in this paper is detailed in Appendix 1. Non-transport capital includes communication, energy, waste water and defense infrastructure. The Penn World Table 6.1 and the Accountant General Annual Reports (various issues) provided the data for the construction of these capital stocks. Ceteris paribus, we expect improved infrastructure to attract more tourists.

The study is based on a panel data of tourist arrivals into the small island of Mauritius over the period 1985 - 2006 from 26 major origin countries, accounting for about $90 \%$ of total arrivals. The countries of origin are: Europe/America/Oceania: Austria, Belgium, France, Germany, Italy, Netherlands, Spain, Sweden, Switzerland, United Kingdom, USA, Canada, Australia Africa: Comoros, Kenya, Malagasy Rep., Reunion, Seychelles, South Africa, Zimbabwe Asia: Hong Kong, India, Japan, Malaysia, China, Singapore

The majority of tourists coming to Mauritius are from Europe (67\%), followed by Africa (25\%) and Asia (8\%). France with 30\% of total tourist arrivals has always been the major source country for Mauritius, followed by the United Kingdom (15\%), the sister island Reunion (13\%), Germany and South Africa (7\%). 


\subsection{Econometric Modeling}

The regression specification in equation (1) is written as a log-linear model:

$\operatorname{tr}_{i t}=\beta_{0}+\beta_{1}$ relative $_{i t}+\beta_{2}$ gdpf $_{i t}+\beta_{3}$ room $_{i t}+\beta_{4}$ dist $_{i t}+\beta_{5}$ inf ras $+\varepsilon_{i t}$

The lowercase letters denote that the variables are in natural logarithm. By adopting a log-linear model, we are implicitly taking the elasticity of tourist arrivals with respect to the different explanatory variables to be constant over the period $1985-2006$.

\subsection{Regression Analysis}

We use panel data techniques as the latter allows for dynamic relations and also for unobserved cross-country heterogeneity. Both fixed effects (FE) and random effects (RE) models have been estimated and the Hausman specification test has been performed to discriminate between them. The Hausman test evaluates the null hypothesis that the coefficients in the random effects and fixed effects models are the same. The Hausman test favors the fixed effect model as can be seen in Table 1.

We estimate the models for total tourist arrivals as well as for tourist arrivals from Europe/America, Asia and Africa. This approach enables valuable comparative insights by informing to what extent the determinants of tourist arrivals from different regions differ, with particular focus here on infrastructure capital. 
Table 2: Panel data estimates: Fixed effects

Dependent variable is $\ln \left(\mathrm{TR}_{\mathrm{it}}\right), 1985$ - 2006

\begin{tabular}{|c|c|c|c|c|}
\hline Variable & Total Tourist Arrivals & $\begin{array}{l}\text { Arrivals from } \\
\text { Europe and US }\end{array}$ & Arrivals from Asia & $\begin{array}{l}\text { Arrivals from } \\
\text { Africa }\end{array}$ \\
\hline $\begin{array}{l}\text { constant } \\
\text { relative } \\
\text { gdpf } \\
\text { rooms } \\
\text { dist } \\
\text { infras }\end{array}$ & 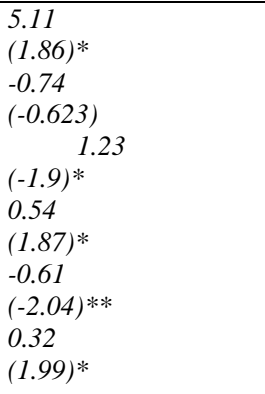 & \begin{tabular}{l}
15.45 \\
$(5.43)^{* *}$ \\
-0.83 \\
$(-1.19)$ \\
\multicolumn{1}{c}{1.84} \\
$(4.11)^{* * *}$ \\
0.67 \\
$(2.18)^{* *}$ \\
-0.67 \\
$(-2.93)^{* * *}$ \\
0.40 \\
$(1.89)^{*}$
\end{tabular} & $\begin{array}{l}7.45 \\
(2.23) * * \\
-0.47 \\
(-3.12)^{* * *} \\
1.51 \\
(1.73) * \\
0.36 \\
(1.77) * \\
-0.25 \\
(-4.42)^{* *} \\
0.11 \\
(1.74)^{*}\end{array}$ & $\begin{array}{l}4.54 \\
(1.59) \\
-0.25 \\
(-1.72 *) \\
0.51 \\
(5.23) * * * \\
0.33 \\
(0.53) \\
-0.14 \\
(-0.21) \\
0.13 \\
(1.34)\end{array}$ \\
\hline$R^{2}$ & 0.74 & 0.81 & 0.75 & 0.58 \\
\hline $\begin{array}{l}\text { Hausman } \\
\text { Test }\end{array}$ & Prob $>$ Chi2 $=0.038$ & Prob $>$ Chi2 $=0.043$ & Prob $>$ chi $2=0.051$ & Prob $>$ chi $2=0.03$ \\
\hline
\end{tabular}

The small letters denotes variables in natural logarithmic and t values are in parentheses

The four equations in Table 2 indicate that infrastructure capital has a positive effect on total tourist arrivals as well as on arrivals from the three regions considered. The coefficient of 0.32 for the case of total tourist arrivals implies that a $10 \%$ increase in the stock of infrastructure capital yields a $3.2 \%$ increase in tourist arrivals in the island. European and American tourists attach sizeable importance (coefficient of 0.40 ) to such capital. This is consistent with the idea that inhabitants of developed countries are accustomed to modern high-quality infrastructure and they prefer to find similar infrastructure in tourism destinations. However Asian and African (coefficients of 0.11 and 0.13 respectively) tourists tend to be less demanding on the infrastructure available in the island.

The coefficient of distance (which may be viewed as a proxy for travel costs) is negative in all four equations of Table 1 and this concurs with theory and previous studies. The distance coefficient is more negative for European and American tourists than for Asian and African tourists. Given that Europe and America are 
further than Asia and Africa from Mauritius, the present finding indicates that tourists prefer shorter to longer journeys so as to minimise travel discomfort.

The positive coefficients on income in country of origin suggest that the Mauritian tourism product is a normal good. This is encouraging especially given that the island is at the very moment planning to rely a lot more on the tourism sector as a source of foreign currency earnings. Tourist arrivals increase by much more from Europe/America (1.84\%) and Asia (1.51\%) than from Africa (0.51\%) as a result of a $1 \%$ increase in income in these respective regions.

On the basis of statistical significance, Table 1 implies that relative prices (Mauritian CPI adjusted for \$ exchange rate) matter for tourists from Asia and Africa but not for tourists from Europe and America. This is consistent with Eilat and Einav (2004) in that tourists are less sensitive to prices when they travel to less developed countries because of the low existing price level. Moreover in the Mauritian context, the European and American currencies have basically been on the appreciation side thus cushioning any increase in price level of the destination. Given that the cost of living in Asia and Africa is relatively less and at most comparable to Mauritius, tourists from these two regions factor in the Mauritian cost of living when deciding whether or not to visit the island.

The variable 'rooms', a proxy for tourism infrastructure, is significant overall and indicates that increased hotel capacity generates more tourist arrivals. Tourists from Europe and America, and to a lesser extent those from Asia, do care about the availability of tourism infrastructure. However, such is not the case for tourists from Africa, where the 'rooms' coefficient is statistically insignificant. This may be explained by the fact that African tourists normally reside at cheaper guesthouses, and not hotels, during their stay. 


\section{CONCLUSIONS}

Although many writers have acknowledged the need for infrastructure in a successful program of tourism development, very limited empirical research exists to shed light on this hypothesis. The effect of such capital on total tourist arrivals and on arrivals from Europe/America, Asia and Africa into Mauritius is investigated in a panel data framework. This paper uses panel data estimation techniques and finds that the infrastructure has been contributing positively to tourist arrivals, particularly from Europe/America and Asia. Moreover tourism infrastructure, relative prices, distance and income in the origin countries are important ingredients in their own respect in the tourism demand equation. The paper also finds that Mauritius is an expanding destination, with the European and American markets being most promising. The findings in this study lend support to the current policy of the government whereby significant marketing effort is being made at the international level to further promote the Mauritius tourism product. The authorities should also be given due credit for constantly upgrading the infrastructure base around the island since the 1980s. However, while not necessarily pertinent at this point in time, the tourism absorption capacity of Mauritius is likely to become a relevant issue in the not too distant future. Research on this issue as well as on the dynamic modeling in tourism should start in the very near future.

\section{REFERENCES}

BALTAGI, B H, EDS . 1995 Econometric analysis of panel data. New York: John: Wiley

CANNING, D. AND BENNATHAN, E. 2000 the social rate of return on infrastructure investments. World Bank Research Project, RPO 680-89, Washington, D.C.

CANNING, D. AND PEDRONI, P. 1999 Infrastructure and long run economic Growth. CAER II Discussion Paper No. 57 
COHEN, E. 1979 A Phenomenology of Tourist Experiences. Sociology 13(2)

CROUCH, G. I., \& RITCHIE, J. R. B. 1999 Tourism competitiveness and societal prosperity. Journal of Business Research. 44(3): 137-152.

CROUCH G.I. AND RITCHIE, J.R.B. 2000 The competitive destination: a sustainability perspective. Tourism Management: 21

EILAT Y AND EINAV L.2004 Determinants of international Tourism: a threedimensional panel data analysis. Applied Economics 36:1315-1327

GALLUP, J, L, SACHS, J.D AND MELLINGER, A . 1997 geography and Economic Development. CID Working Paper no.1. Harvard University

GEARING, C.E. 1974 Establishing a measure of touristic attractiveness. Journal of Travel Research 12: 1-8.

GUNN, C.A, EDS. 1988 tourism planning (second edition). New York: Taylor \& Francis.

HESTON A, R SUMMERS AND ATEN B. 2002 penn world table version 6.1. Center for International Comparisons at the University of Pennsylvania (CICUP)

INSKEEP, E. 1991 Tourism Planning: an integrated and Sustainable Development approach. New York, Van Nostrand Reinhold

KAMPS, C. 2003 New estimates of government net capital stocks for 22 OECD countries 1960-2001. Kiel Institute for World economics, 24100, Kiel, Germany 
KAUL, R. N, EDS. 1985 Dynamics of tourism: a trilogy (vol. 111) Transportation and Marketing. New Delhi

KIM L, CROMPTON J, L , BOTHA, P. 2000 Responding to competition: a strategy for Sun/Lost City. South Africa Tourism Management .21 (41)

LIGHTHART, J.E. 2000 Public capital and output growth in Portugal: an Empirical analysis. IMF working paper. WP/00/11

LIM C. 1997 Review of international tourism demand models. Annals of Tourism research. 24, (4): 835-849

MCELROY J, L. 2003. Small island tourist economies across the lifecycle, Paper prepared for the International Conference, Beyond MIRAB: The Political Economy of Small Islands in the $21^{\text {st }}$ Century, School of Economics and Finance, Victoria University, Wellington, New Zealand, 23-25 February 2004

MO, HOWARD AND HAVITZ 1993 Testing a tourist role Typology. Annals of tourism research. 20: 319-335

MURPHY P, PRITCHARD M, SMITH, B. 2000 the destination product and its impact on traveler perceptions. Tourism Management 21: 43-52

NAUDEE W A, SAAYMAN A. 2004 the determinants of tourist arrivals in Africa: A Panel Data Regression Analysis. Paper presented at the International Conference, Centre for the Study of African Economies. University of Oxford.

PRIDEAUX B. 2000 the role of the transport system in destination development. Tourism Management 21: 53-63 
SINCLAIR, T. 1998 tourism and economic development: A survey. Journal of development studies: 34(5): 1-51.

SMITH, S. L. J. 1994. The tourism product. annals of tourism Research. 21(3): 582-595.

STURM, J.E. AND DE HAAN, J. 1995A. Is public expenditure really productive? New evidence from the USA and the Netherlands. Economic Modeling. 12(1), 60-72.

TANG AND ROCHANANOND. 1990 Attractiveness as a tourist destination; a comparative study of Thailand and selected countries. Socio-Econ Planning 24(3)

TOURISM TASK FORCE (TTF). 2003 down the track; Better Ways To deliver tourism's land transport infrastructure: Available on www.ttf.org.au

WITT S AND WITT C . 1995 Forecasting tourism demand: A review of empirical research. International Journal of Forecasting: 11:447-475

WTO. 2003 tourism highlights. World tourism organization: madrid.

U.S BUREAU OF ECONOMIC ANALYSIS. 1999. fixed reproductible tangible wealth in the US 1925-1994[online]. Washington D.C. Available from: http://www.bea.doc.gov/bea/articles/ NATIONAL/NIPAREL /Meth/ wlth2594.pdf. 